\title{
Interrogating the Concept of 'Community' in Community Policing Operations in Nigeria
}

\author{
1,a* Ogadimma Arisukwu, , ${ }^{1, a}$ Tunde Adebisi, 1,bChisaa Igbolekwu, ${ }^{1, a}$ Festus Asamu \\ ${ }^{a}$ SDG 16, Peace, Justice and Strong Institutions \\ ${ }^{\mathrm{b}}$ SDG 10, Reduced Inequality \\ *First and corresponding author \\ ${ }^{1}$ Department of Sociology, Landmark University
}

\begin{abstract}
Community is a veritable ingredient for social change and development in a society.

The potentials of individuals and groups in the community are a great source or resource for promoting unity, development and patriotism. The general objective of this study is to examine the influence of diversity in community composition, on the operation of community policing style in Nigeria. The study adopted qualitative research approach to collect and analyze data. In-depth interview is the instrument of data collection while content analysis is the method of data analysis. The study took place in Kwara State, North central Nigeria. Twenty community leaders and youth groups heads were purposefully selected through snowball sampling method. Where this great resource or human capital is adequately galvanized by the leaders and community heads, the community becomes formidable and capable of solving her social problems together. However, these benefits of community are hampered by other socio-cultural and economic variables in its members. Community on its own cannot achieve much until members are mobilized to support and partner with government in any developmental projects.
\end{abstract}

Key words: Community; Human Capital; Socio-Cultural; Mobilization; Partnership; Development

Word count: 176

\section{Introduction}

The clamor for the adoption of community policing style in solving Nigerian security challenges has become loudest owing to poor police-public perception and poor crime management by the police (Okeke, 2020). The Police are incapacitated more by poor staff strength, low motivation and corruption, to fully engage in internal security functions. In fact mere police presence during political protests and unrests often exacerbate the crisis, (Baudains, Belur, Braithwaite, Marchione, \& Johnson, 2019; McNamara, \& Quilter, 2019). The police are the closest security agencies encountered by the public in their everyday lives in the society. The daily interactions members of the public have with the Police often leaves them with nasty Police brutality and maltreatment. For instance; the brutal murder of George Floyd in America by Police officer has generated global condemnation of Police abuse and use of brutal force on minority populations in the society (Jeffers, Siddiq, Martinez-Hollingsworth, Aronowitz, Sinko, Travers \& Gutierrez Jr, 2020). This public condemnation of police brutality has shared the same platform with the "No Room for Racism" campaign and the "Black Life Matters Movement" in the world of Sports (Hylton, 2020). 
Similarly in Nigeria, the \#EndSars movement generated lots of solidarity against poor policing in the country (Miah, 2020; Umegbolu, 2020). Although the Police occupy a sensitive position in a society; in the first place they are the law enforcement arm of the government who employ some level of force in the process of doing their law enforcement duties. On the other hand the Police is expected to serve the citizenry who often call them when in need. Policing therefore entails the balancing of law enforcement with service to the public. Unfortunately, Police brutality has been recounted as a deliberate and conscious use of excessive force on citizens by the Police (Chevigny, 2008; Akinlabi, 2020 Aborisade \& Oni, 2020).

As the most visible security agency in the country, it is expected that the public will readily notice the ills of the Police more than those of other sister security agencies. To control crime better and ensure public participation and police accountability in crime management, community policing style has become the toast of government and the general public (Arisukwu et al., 2020; Sedgwick et al., 2020; Qu et al., 2020; Diphoorn \& van Stapele, 2020). The people are expected to be part of the policing architecture and operations. This will help reduce poor public-perception of police and police brutality in the country.

Nigeria is a multi-cultural and religious country with over 450 ethnic nationalities and languages covering the length and breadth of the country. Each ethnic group is unique and often strives to stay on its own. Consequently, most conflict and crisis in Nigeria are usually ethnic, religious, economic and politically based (Ezeogidi, 2020). This has built a culture of mistrust and fear of subjugation among these ethnic groups (Ndiribe \& Aboh, 2020). This complicated social integration and interaction manifested in government policies. People view government polices with ethnic and religious lenses thereby making it difficult for objectivity and merit to thrive (Yunusa, 2011).

Community is a concept that describes people bound together by common culture, norms and values (Räsänen et al., 2020). Community members also engage in one form of social interaction or another. It is the social interactions among members of a community that makes them a strong social force or resource capable of achieving any set goal amongst them with a leader who understands the complexities and social dynamics of the community members and is willing to explore these potentials.

Community often has same sense of belonging and feelings of security and patriotism. The concept of social bonds among community members and with their leadership is what propels development and motivate public participation in them.

\section{Statement of Problem}

Community policing thrives where every member of the community has a sense of belonging and has the opportunity to participate in crime prevention and problem solving efforts in the community. Even the police need to operate as members of the same community and not mere 
agents of government. The 'we' and 'them' feeling between the police and members of the public will not augur well for a crime free community through community policing.

In Nigeria, where there exist complains of neglect and marginalization by youths and other minority ethnic groups, galvanizing these conflicting groups to be part of community policing will be a challenging task. A community where some groups do not trust each other cannot effectively come together to partner with the police through community policing. Police in Nigeria are perceived to be instrument of coercion of the government often deployed against a target group in the society. The targeted groups usually are the minority ethnic groups, youths and other socioeconomic and religious considerations. Community participation in crime prevention and control is facilitated by a sense of belonging and stake holder's mentality of various groups within a society. The absence of this value consensus creates a gap of mistrust and lack of support in any community project including community policing.

\section{Research Objectives}

The general objective of this study is to examine the influence of diversity in community composition, on the operation of community policing style in Nigeria.

\section{Methodology}

The study adopted qualitative research approach to collect and analyze data. In-depth interview is the instrument of data collection while content analysis is the method of data analysis. The study took place in Kwara State, North central Nigeria. Twenty community leaders and youth groups heads were purposefully selected through snowball sampling method. Kwara was divided into three senatorial districts and a local government area was purposively selected. The selected local government areas were further divided into wards and a compound or kindred selected. A compound head, women and youth leaders were selected through snowball sampling technique. The study equally adopted journals as secondary source of data.

\section{Theoretical frame work}

The study adopted social capital theory as propounded by Bourdieu and Coleman to explore the potentials and capacity of human beings to contribute to socio-economic development of their community. This theory considers humans as a resource when people think or act in a collective and cooperative manner. To this end, human beings are needed for community policing to be effective and beneficial to all in a society. How this human resource capital is managed by leaders and government will determine the extent of cooperation, participation and support they will give in their community. Community policing operations in Nigeria will be enhanced when ethnic, religious, age and gender sentiments and inequality are eradicated and the people see themselves as a team focused in crime reduction and problem solver in a community.

\section{The Concept of Community}


The concept of community is used often to show 'being in common', (Neal, Bennett, Cochrane, \& Mohan, 2019). It is the social bonds that people share that binds them together into a community. The bonds are often re-enforced by common norms, values, culture and general world view or perspectives. It is this togetherness or unity that makes any member's issue to become every body's issue. Community confers on members some benefits and responsibilities. Community gives members a voice in championing their desires and expectations from outsiders or government. Community depicts what it means to be human and social, (Räsänen et al., 2020; Wills, 2016). This position was supported by an interviewee who said;

I believe when the people see themselves as one, there is no problem they cannot conquer. Community provides the canopy that shelters every member from harassment and mishap. What you cannot confront alone can be subdued through community efforts. (IDI Community Leader in Kwara State, November, 2020)

However, (Studderet and Walkerdine, 2016) in examining community focuses on 'what community does' rather than 'what community is'. So in re-thinking community, emphasis is now on what the community unites to do rather than place or neighborhood locations. The social media has created a platform where community can be created and joined on line without any physical contact. The online community creates and champion social courses that empower and lead to social change and development in society. This position was supported by an interviewee who said;

Coming together to support any course is the major reason for having a community. These days you can join virtual communities online to raise a concern and fight a course. Social media helps us to connect from anywhere regardless of your sociocultural or economic background for any just course. In fact it is easier and safer to join a social media community to challenge government than to physically challenge or resist government policy in Nigeria. (IDI Youth leader in Kwara State, November, 2020).

On the other hand, Rogaly, 2016, Swann \& Hughes, 2016) used place based research in their study of community. This place based community helps researchers to observe and analyze social relations within the community they study. It is important to point out that community in community policing operations refers to human beings who dwell and interact within a physical territory. Another interviewee had this to say;

We the people is the strongest force that you can think of. When people are mobilized to fight any just course that is for the general good, the society is always better. Here our youths are adequately mobilized and ready to support government or the police to reduce crime. We patrol and secure our area every night with cutlass and sticks. (IDI Youth leader in Kwara state, November, 2020).

\section{Community participation}


The real benefit of community lies in the ability to harness potentials of members to achieve or identify development projects and social challenges respectively. It is in putting the social capital available in a community that development and participation with government are realized. So the issue is not just to have people living and sharing things in common, but how they can be galvanized into a developmental force, or enlightened to become agents of social change in a society. Community participation is central to the success of most developmental and health projects (Chuah, Srivastava, Singh, Haldane, Koh, Seng \& Legido-Quigley, 2018). An interviewee supported this position by saying;

In this our area, there are lots of people available. But a good community leader has to device a means of reaching out to people to support in community development. Through the support of community members here we were able to repair our health centre for the benefit of all especially pregnant women. People are always there but you need to organize or ask them to help out. (A community leader in Kwara state, November, 2020).

Community participation is therefore the engagement or involvement of the community both as individual members and as a community in socio-economic, political and heath related developmental projects (Montesanti, Abelson, Lavis, \& Dunn, 2017). The World Health Organization, (2002), defines community participation as "a process by which people are enabled to become actively and genuinely involved in defining the issues of concern to them, in making decisions about factors that affect their lives, in formulating and implementing policies, in planning, developing and delivering services and in taking action to achieve change". So community participation begins with involving the community members in identifying the problem or project to be carried out and taking part at every stage of the project and monitoring its performance after completion. It is the involvement of the community from conception and to implementation of the project that gives them a sense of ownership and belonging needed to make the project sustainable (Serapioni, \& Duxbury, 2014). An interviewee said;

The problem with our government is that they always think that they know everything. Most time they decide what the community deserved and from experience these projects were abandoned and not supported by the people. A case in point is when we needed construction of a major road to assist in evacuating farm produce; rather the government gave us street light. (IDI/a youth leader/Kwara state /2020).

The beauty of democracy as a system of government is the opportunity granted to citizens to participate in governance and to add their voice or voices either as individuals or groups to how best they are to be governed. Policing and security are very sensitive things in the society that require people's contribution and support for it to be successful. Participation is a profound means of support of government by the people. In Nigeria, the primary purpose of government is to provide welfare and security of lives and property of the people. This profound desire of government can only become reality with adequate engagement and participation of the people. 


\section{Gender issues in community participation}

Gender is implicated in all social, political, economic and religious actions and social interactions in the society. Gender is supported by culture and upheld by religion. Thus, women in Africa and Nigeria in particular are treated as mere objects of sexuality, which do not matter much in the community (Yta, 2020; Popoola, 2020). Women are considered as properties to be secured by men, and are therefore often neglected and abandoned when considering security issues in the community (Akpomuje \& Mejiuni, 2020). Women are not included in security committees and do not form part of the community policing operations in most states in Nigeria. Though women have the most population in Nigeria, yet they are not fully represented and included at the decision making levels in the community. This gap has created gender imbalance in every sector of the Nigerian society. An interviewee had this to say;

In this our community, women do not have any voice or contributions in all community decisions and projects, The men conceive and decides what happens here, regardless of how such decisions or projects will affect the girl child or women. We just follow whatever that comes from men. Women are more in this community. Most of them are full time house wives who are always at home yet none of us is part of the community policing or security committee. The men think they know it all. (IDI/Woman leader/Kwara state/November/2020).

Girl child is socialized not to dream big and pursue lofty desires in life. This has deprived the community and nation the potential contributions of women as significant members of the society. Most times women and children form the major victims of insecurity in the community, yet they are not given a voice and place in the community policing operations of their community. Patriarchy has sustained the deprivation and marginalization of women as responsible members of the communities and nations.

\section{The place of young people in the community}

The neglect of young people in the day to day decision making process in most communities in Africa and Nigeria speak volumes (Adebisi et al., 2020). The young people and youths form the largest uneducated and unemployed population in Nigeria (Okolie \& Igbini, 2020). Most youths engage in some perilous journeys to Europe and America just to escape poverty and hardship. These youths and young people feel disconnected from the communities and governments in their states and nations. In an attempt to survive on their own, most of these youths and young people engage in one antisocial behavior or another (Adebisi et al., 2020). Youths are equally the targets of police brutality and maltreatment in the communities in Nigeria. This ill treatment of youths by some policemen creates disenchantment, hate and lack of trust of the police and government by the youths. An interviewee had this to say; 


\begin{abstract}
Most youths in this community are unemployed. The government has no genuine program to empower us here. It is only during election that we see our political leaders who promise us jobs, but as soon as they win all promises are forgotten. The youths are not happy. Some are frustrated to the point that they have started taking drugs and excessive alcohol. These frustrated youths are the ones engaging in anti-social behaviors like rape, robbery and arson. As a result, the police here believe that all youths are criminals and treat them as such. (IDI/Youth leader/Kwara state/November/2020).
\end{abstract}

The elderly in most communities assume the position of leadership. Youths are perceived to lack wisdom and understanding (Marzana et al., 2020). This is wrong because most nations of the world are propelled into wealth and good governance by youths. Youths are the labor force that sustains wealth creation and development in the society.

\title{
Status of community members
}

The status of members of the community could make them to support or ignore community initiatives such as community policing operations. The immigration status of immigrants has implications on their socio-economic conducts and willingness to participate in community operations (Makki Alamdari, 2020). Immigration status makes one to consider him or herself as a member of the community. Also sexual orientations create social barriers among members of the same community and hinder willingness to contribute or participate in community developmental efforts. Gays and lesbians are often discriminated against in Nigeria, making it impossible for them to have a sense of belonging and ready to make any positive contributions in their communities (Giwa et al., 2020). Apart from immigration status, in Africa and Nigeria in particular, ethnic and religious affiliations affect the willingness of people to see themselves as members of their community and participation in community operations. To support this position an interviewee said;

The major obstacle to community participation here is religion and ethnicity. Everything is given religious and ethnic interpretations. So those that feel negatively imparted or neglected in the project will kick against it. Recently we are witnessing people supporting and mobilizing their political groups instead of the entire community. Politicians use divide and rule to put the people against themselves. (IDI/Community leader/Kwara state/November/2020).

In Nigeria there are indigenes and settlers within the same community, with indigenes laying more claims as the original owners of the land and settlers seen as second class members of the same community. This segregation affects unity, peace and willingness to participate in community operations. The community is equally made up of rich and poor members. The poor lack sense of belonging due to aggression, frustration and poverty, while the rich often suspects and looks down on the poor. Security issues are seen by the police to be caused by the poor more than the rich. The police target the poor in their policing operations leading to large number of poor youths in police 
custody in Nigeria. This lack of trust by the rich over the poor generates a gap in community participation in operations like community policing.

\section{Conclusion}

Though community constitutes a vibrant resource for sustainable development at the community levels, the social, cultural and economic categorization of members could become a clog in the wheel of progress of the community. It is not enough to have enough individual or group potentials available in a community, but how they are treated by the same community could hamper their sense of belonging and willingness to participate in community policing operations. Good governance and service to the people should be the major motivation in selecting leaders at the community level to promote community development and peaceful coexistence of all.

\section{Recommendation}

Peace building efforts should be promoted by family, government and religious leaders in the community.

Obnoxious cultural practices such as caste system and negative widowhood practices are to be abolished.

Free and sincere leadership recruitment process, good governance, job creation and social justice will sustain the bonds uniting community members together and trigger effective sense of belonging among members.

Bottom-top approach should be adopted in conceiving and implementing community projects.

Youths and women should be properly integrated in community committees and decision making in the community.

\section{References}

Aborisade, R., \& Oni, S. F. (2020). “Crimes of the Crime Fighters": Nigerian Police Officers' Sexual and Physical Abuses Against Female Arrestees. Women \& Criminal Justice, 30(4), 243-263. https://doi.org/10.1080/08974454.2019.1632774

Adebisi, T., Alabi, O., Arisukwu, O., \& Asamu, F. (2020). Gambling in Transition: Assessing Youth Narratives of Gambling in Nigeria. Journal of Gambling Studies, 0123456789. https://doi.org/10.1007/s10899-020-09982-x

Akinlabi, O. M. (2020). Citizens' accounts of police use of force and its implication for trust in 
the police. Journal of Crime and Justice, 43(2), 145-160. https://doi.org/10.1080/0735648X.2019.1650798

Akpomuje, P., \& Mejiuni, O. (2020). Key gender issues in the military education in Nigeria and a call for gender-sensitive security sector reforms. Journal of Adult Education, 2(1), 2281. https://journals.unza.zm/ Online ISSN 2664-5688.

Arisukwu, O., Igbolekwu, C., Oye, J., Oyeyipo, E., Asamu, F., Rasak, B., \& Oyekola, I. (2020). Community participation in crime prevention and control in rural Nigeria. Heliyon, 6(9), e05015. https://doi.org/10.1016/j.heliyon.2020.e05015

Baudains, P., Belur, J., Braithwaite, A., Marchione, E., \& Johnson, S. D. (2019). The exacerbating effect of police presence: A multivariate point process analysis of the Naxal conflict. Political Geography, 68, 12-22.

Chuah, F. L. H., Srivastava, A., Singh, S. R., Haldane, V., Koh, G. C. H., Seng, C. K., ... \& LegidoQuigley, H. (2018). Community participation in general health initiatives in high and uppermiddle income countries: a systematic review exploring the nature of participation, use of theories, contextual drivers and power relations in community participation. Social Science \& Medicine, 213, 106-122.

Diphoorn, T., \& van Stapele, N. (2020). What Is Community Policing?: Divergent Agendas, Practices, and Experiences of Transforming the Police in Kenya. Policing: A Journal of Policy and Practice. https://doi.org/10.1093/police/paaa004

Ezeogidi, C. (2020). The Socio-Economic Consequences of Protracted Conflicts in Post Colonial Nigeria. SSRN Electronic Journal. https://doi.org/10.2139/ssrn.3563480

Giwa, S. A. O., Logie, C. H., Karki, K. K., Makanjuola, O. F., \& Obiagwu, C. E. (2020). Police violence targeting LGBTIQ+ people in Nigeria: Advancing solutions for a 21 st century challenge. Greenwich Social Work Review, 1(1), 36-49. https://doi.org/10.21100/gswr.v1i1.1108

Hylton, K. (2020). Black Lives Matter in sport...? Equality, Diversity and Inclusion. https://doi.org/10.1108/EDI-07-2020-0185

Jeffers, K. S., Siddiq, H., Martinez-Hollingsworth, A. S., Aronowitz, S. V., Sinko, L., Travers, J. L., ... \& Gutierrez Jr, J. I. (2020). Nurses should oppose police violence and unjust policing in healthcare.

Makki Alamdari, S. (2020). Civic Attitudes and Engagement Among Middle Eastern and North African Refugees and Immigrants in the U.S. Advances in Social Work, 20(1), 114-131. https://doi.org/10.18060/23687

Marzana, D., Alfieri, S., Marta, E., \& Paloma, V. (2020). Community Involvement as a Vehicle for Integration: A Study with Young Immigrants. Journal of Civil Society, 16(2), 138-157. https://doi.org/10.1080/17448689.2020.1752020

Miah, M. (2020). BLM stands with Nigeria's \#EndSARS movement. Green Left Weekly. https://search.informit.com.au/documentSummary;dn=513431541646153;res=IELHSS 
McNamara, L., \& Quilter, J. (2019). Criminalising protest through the expansion of police 'moveon'powers: A case study from Australia. International Journal of Law, Crime and Justice, $58,22-34$.

Montesanti, S. R., Abelson, J., Lavis, J. N., \& Dunn, J. R. (2017). Enabling the participation of marginalized populations: case studies from a health service organization in Ontario, Canada. Health promotion international, 32(4), 636-649.

Neal, S., Bennett, K., Cochrane, A., \& Mohan, G. (2019). Community and conviviality? Informal social life in multicultural places. Sociology, 53(1), 69-86.

Ndiribe, M. O., \& Aboh, S. C. (2020). Multilingualism and marginalisation: A Nigeria diversity approach. International Journal of Multilingualism, 1-15. https://doi.org/10.1080/14790718.2020.1818752

Okeke, C. O. (2020). Effective Policing: A Panacea for Resolving Conflict Between Policemen and The Public. Nigerian Journal of African Studies (NJAS), 2(2). https://nigerianjournalsonline.com/index.php/NJAS/article/view/1353

Okolie, U. C., \& Igbini, M. D. (2020). Leadership Failure and Acute Youth Unemployment in Nigeria. RUDN Journal of Public Administration, 7(3), 254-271. https://doi.org/10.22363/2312-8313-2020-7-3-254-271

Paul G. Chevigny,(2008). Police Brutality,Encyclopedia of Violence, Peace, \& Conflict (Second Edition),Academic Press,Pages 1612-1621,ISBN 9780123739858,https://doi.org/10.1016/B978-012373985-8.00135-5.

Popoola, R. O. (2020). 'I Thought She Was Ordinary, I Only Saw Her Body': Sex and Celebrity Advocacy in Nigerian Popular Culture. Journal of African Cultural Studies, 1-15. https://doi.org/10.1080/13696815.2020.1762169

Qu, J., Wang, X., \& Zhao, J. (Solomon). (2020). Correlates of the endorsement of two competing policing styles among police cadets in China. Police Practice and Research, 21(3), 313-328. https://doi.org/10.1080/15614263.2019.1582341

Räsänen, A., Lein, H., Bird, D., \& Setten, G. (2020). Conceptualizing community in disaster risk management. International Journal of Disaster Risk Reduction, 45, 101485. https://doi.org/10.1016/j.ijdrr.2020.101485

Rogaly, B (2016) 'Don't show the play at the football ground, nobody will come': The microsociality of co-produced research in an English provincial city. The Sociological Review 64: 657-680.

Sedgwick, D., Callahan, J., \& Hawdon, J. (2020). Institutionalizing partnerships: a mixed methods approach to identifying trends and perceptions of community policing and multi-agency task forces. Police Practice and Research, 1-18. https://doi.org/10.1080/15614263.2020.1712204

Serapioni, M., \& Duxbury, N. (2014). Citizens' participation in the Italian health-care system: the experience of the Mixed Advisory Committees. Health Expectations, 17(4), 488-499. 
Studdert, D, Walkerdine, V (2016) Being in community: Re-visioning Sociology. The Sociological Review 64: 613-621

Swann, R, Hughes, G (2016) Exploring micro-sociality through the lens of 'established-outsider' figurational dynamics in a South Wales community. The Sociological Review 64(4): 681698.

World Health Organization. (2002). Community participation in local health and sustainable development: Approaches and techniques.

Umegbolu, C. (2020). End SARS: A Revolution by the people for the people on police brutality in Nigeria. $\quad$ https://research.brighton.ac.uk/en/publications/end-sars-a-revolution-by-thepeople-for-the-people-on-police-brut

Wills, J (2016) (Re)locating community in relationships: Questions for public policy. The Sociological Review 64: 639-656.

Yta, E. M. (2020). Objectification of women in carnival Calabar: an emerging paradigm. International Journal of Humanities and Innovation (IJHI), 3(2), 79-86. https://doi.org/10.33750/ijhi.v3i2.78

Yunusa, U. (2011). Evaluating Ethnic and Resource Conflicts In Nigeria and Challenges for National Security and Democratic Governance. The Educational Psychologist, 12(1), 37-47. 